\title{
CUSTOMARY RIGHTS: HOLDING THE LINE
}

\author{
EDWARD ELLISON
}

Public History ReVIEW, VOL 13, 2006, PP86-94

\section{oi tu te marae o Tangaroa \\ Toi tu te marae o Tane \\ Ka ora ai te iwi}

\section{DETERMINING CUSTOMARY RIgHTS}

Cultural identity is underpinned by custom and whakapapa that bind a people to place and resources, the rights that flow, and exercised generation by generation. In the case of Kai Tahu, establishing who has specific customary rights is determined by the following lore:

Umu takata: rights through conquest

Take whenua: an inherited right

Mahi takata: an ancestral right proven because of discovery and subsequent naming of land and resource

Tuturu te noho: rights of settlement, which are only valid if there is an established inter generational permanence

Kai taoka: exchange of land or resource for taoka

Tuku whenua: the gifting of land and resource in traditional times prior to European contact

Take tupuna: a right that can be established because an ancestor has asserted themselves over land or a resource

All of the above requires scrupulous attention to detail regarding whakapapa, tradition and knowledge of the way ancestors obtained their customary rights, and applied succession over generations to the current day. At any point events could add to or remove customary rights according to the criteria in italics above. This was a natural reality to the ancestors as was the rising of the sun each day, something to be mitigated through careful management of relationships, and attention to customary rules that ordered their society. Success or failure in traditional times meant life or death, prosperous families or desperate times, in many instances the key to success was arranging marriages to bring opposing sides together in blood ties. Every action had a consequence, all things were inter 
connected, values and beliefs were based on a holistic world view, people were a part of and related to the environment that they lived in, traditions, placenames, burial sites, waiata and other cultural appendages that reinforce connection. This is part of lore, influential in determining rights and the nature of relationships that whanau and hapu hold with place, resource and status within the tribal network.

\section{TREATY OF WAITANGI}

The signing of the Treaty of Waitangi locked a window in time for perpetuity, removing the ebb and flow of Maori society and stabilizing boundaries and customary rights as they existed at 6 February 1840. The Treaty attempted to recognize and protect through Article II, the rights and powers of each party, in particular in this context is the compact to protect the unqualified exercise of chiefly authority Maori / Kai Tahu had over their lands, villages, taoka (treasures), sacred sites and waters. Erosion of the spirit of the Treaty had a savage effect on the capacity of iwi to make the transition to a post treaty society with customary rights and social structures intact.

The colonial parliaments introduced a long period of denial to the rights of tangatawhenua, for example establishing the Maori Land Court system in the 1850 's essentially to alienate lands held by Maori to meet the clamour for land by new settlers. Maori communal commercial enterprises were to fore in the new colony, able to operate at a lower cost level than their settler 'free enterprise' counterparts, it was not long before the Maori traders were sidelined by the growing number of immigrants who became less reliant on Maori goods and who preferred to trade with their own.

Meanwhile Maori access to lands, resources, to hunt and gather to supplement the needs of whanau and hapu became increasingly difficult through land loss, removal of native flora, poisoning of native fauna and the growth in area of 'private land' and application of trespass restrictions.

A succession of laws and the associated administration of them was virtually exclusively dominated by Pakeha, the Maori voice was absent, as a result by the 1960's Kai Tahu were a marginalized people, struggling to hold the line on access to customary resources, and depletion of what little Maori land was left.

The idea that Maori/ Kai Tahu might have a view on all of this did not seem to register, and generations of decision makers must have exercised their 'authority' in blissful remoteness from the realities of accountability to the right holders on issues that were central to the cultural health of Maori.

This is not to say that Maori/ Kai Tahu were altogether silenced, they continued over the generations to seek justice to their land claims and to give life to the promise the Treaty of Waitangi offered at the time of its signing in 1840. Significant events such as the 1975 Maori Land March, Bastion Point evictions, environmental issues such as Motunui waste discharges, South African ban on Maori players and Te Maori all combined to awaken awareness of the other culture in this country and identify that there were unresolved issues. 


\section{RECOGNITION PERIOd}

So we emerge into and era where the recognition of Maori and the treaty was incorporated into some important legislation such as the Treaty of Waitangi Act 1975, State Owned Enterprises Act 1986, Conservation Act 1987, RMA Act 1991, Maori Fisheries Settlement Act 1992. Also introduction of treaty settlement processes offered the chance for our people to have their 'day in court', at last being able to express in their own words and in their own settings the pent up feelings and suffering that systematically eroded land holdings, resources and any recognition of the age old rights that the treaty sought to protect. At last our people were able to dream of a better future, for their descendants, a future where the state would acknowledge their sins, and self determination by hapu and iwi would be possible, the grievance mindset put to rest.

\section{KoIWI TANGata: Human Remains and Repatriation}

This new found enlightenment set the scene for mature discussions on issues such as the holding of human remains as collection items in institutions, public display of toi moko (Maori preserved heads) and conducting research on koiwi tangata (human remains) with out the consent or knowledge of the hapu and or iwi from whose burial grounds they may have been taken. Attitudes that 'scientific inquiry' was legitimate regardless of who the remains might be connected to by way of whakapapa became open to question. The idea that 'ownership' of human remains was repugnant, physical handling and research practices with out the consent of the affected kin group gained currency. The fact that koiwi were recognized as having links to real life communities was significant, in the case of Kai Tahu resulting in a high degree of collaboration by authorities in repatriation of koiwi to designated 'keeping places' nominated by Kai Tahu. The spiritual connections and customs of the tangatawhenua were given legitimacy in this process. It is worth noting that there has been a nation wide response to repatriation of human remains, and recently an international project to seek the return of koiwi held in overseas institutions.

\section{KaWa Hua Taiao: Cultural Materials and Customs}

The definition of indigenous people is 'the people who are present, who have established customs and connection to place, who are resident when other people arrive from far of lands, who bring with them new values, practices and technology'. Another area of customary rights under siege has been the conservation scene, where legislation such as the National Parks Act 1980, Reserves Act 1977, Marine Reserve Act 1971, Wildlife Act 1977 and Conservation Act 1987 embody a philosophy of protectionism or lock up that conflicts with the sustainable use philosophy that underpins customary use practice of hapu and iwi.

An underlying concept in the conservation laws is a belief that people and the environment are not connected, that in order to achieve protection people are best kept out of special places, or admitted under strict rules that have the effect 
of disconnection for manawhenua. Not withstanding the fact that skifields, roading, aircraft landing, deer hunting, grazing, tramping tracks and huts, scientific research, large numbers of tourists and numerous concessionaires are able to utilise our national parks and conservation areas. Maori seeking to have customary rights upheld, to retain access to cultural materials on conservation lands run into blockages. Despite the fact the Tuwharetoa chief Te Heuheu gifted to the nation the mountain Tongariro and as a consequence the nations first national park was created, the laws that grew around conservation lands failed to honour customary rights. In effect the conservation laws have been dominated by the view that Maori customary rights are a threat to conservation values, a perception that any 'concession' will lead to plunder and pillage of birds and trees. There is a paternalistic hangover at play, a monocultural attitude that clashes with the cultural concept of kaitiakitanga (traditional guardianship) based as it is on a spiritual connectedness and interactive relationship. The gathering of customary materials, making traditional tools, garments and even for particular ceremonies to take edible items are central to the maintenance of age old practices and the retention and traditional knowledge associated with such practice.

\section{CUSTOMARY RIGHTS}

Customary rights are given specific protection under Article II, they can also be converted to legal status through legislation. Customary rights were in place prior to the treaty, the treaty can be viewed as a human rights law. Almost every culture, religion or philosophical belief system displays the fundamental principles of human rights to one degree or other, the relationship between the ruled and rulers, how society addresses such questions, is influenced by custom that evolved over the ages, it is not a recent phenomena. Precedents were established by the Magna Carta 1215, 1688 English Bill of Rights, American 1791 Bill of Rights, similarly the French Revolution was about removing an absolutist monarchy to achieve liberty based on equality of rights. However collective rights as exist for indigenous peoples, which are framed on custom and tradition, have struggled to be recognized. States are clearly recognized in international law, states however focus on individual human rights and not to communal rights which is a core element of indigenous communities.

The totalitarian power of our parliament is not exampled anywhere else in the world, we are unique in that respect, checks and balances that might be constrained by the constitution such as the US might have or the various upper houses or senates apparent in other democracies. Maori custom is hinged on reciprococity, the treaty reflects that, commonly referred to as 'partnership', however equal that may have been intended. The current situation, however, is that all power rests with the state, and customary rights are at the mercy of the decision makers.

Government response to the Court of Appeals ruling that hapu and iwi had an avenue to determine ownership of the foreshore and seabed, was to create 
the Foreshore and Seabed legislation that effectively constrains interpretation of customary rights to a narrow framework of rights. The reason being to provide certainty for those who use and administer the law, affirming the principle of regulation, public access and customary rights. Hapu and iwi took the view that this was a denial of rights, confiscation in effect and objected strongly.

\section{United Nations the Permanent forum on Indigenous Peoples (PFII)}

On the domestic scene iwi exhausted domestic options available to them to reverse government intention of legislating over the top of customary rights. Actions which included participating in statutory processes of select committee hearings, lobbying and of course the Foreshore and Seabed march on parliament. Ngai Tahu and Treaty Tribes then began to look at international options, noting that NZ was a signatory to the International Decade of Indigenous Peoples, and that the General Assembly of the UN had called on 'states to ensure indigenous peoples attain meaningful realization of these basic and ostensibly universal rights (Resolution A/50/107)'.

The United Nations have established that the founding human rights instruments codified uncontested rights to:

The rule of law

Access to the courts

Non-discrimination

The right to a remedy for the violation of human rights

The international decade on indigenous peoples reinforced that these civil and political rights are also enjoyed by indigenous peoples. So it was on this basis that Ngai Tahu and Treaty Tribes took the case to the United Nations Permanent Forum on Indigenous Issues (PFII) in May 2004, presenting interventions to this assembly on Human Rights, Culture, Environment and Social Development, identifying serious issues associated with the Foreshore and Seabed Bill as follows.

\section{Culture}

The government was intending to extinguish our property rights to the foreshore and seabed, irrevocably severing our customary relationships.

Would require us to go to court to have our ancestral connection recognized by the State, but the courts will apply a statutory test that bears no relationship to our customary law.

Result in our customary practices being restricted, reduced, and subservient to practices of the State, and third parties.

The Forum was asked to 'Assert that states should unreservedly, respect customary law and relationships; and the State of NZ should take immediate steps to implement the substantive realisation of cultural pluralism through abandoning its intent to pass the Foreshore and Seabed Bill.' 


\section{Human Rights}

Government intervention in due process of the courts for the purpose of legislating over a decision of the Court of Appeal that upheld Maori access rights to the courts.

Extinguishing the jurisdiction of courts to investigate and declare extant customary property rights.

Discriminating against Maori on the basis of ethnicity for the purpose of political expediency.

The Bill was drafted subsequent to a specialist tribunal finding that the policy preceding the Bill was contrary to domestic and international standards, representing a clear example of:

(a) The rule of law being over ridden

(b) A breach of the principles of equality and non discrimination

(c) No judicial remedy available for those breaches of human rights.

\section{Economic and Social Development}

Maori would be denied to 'Benefit commercially from the foreshore and seabed', despite this being common customary practices and participate, as of right, in the ventures of third parties who will commercially exploit the foreshore and seabed. Nor could they benefit from future commercial development of the entire coastal marine area.

The main remedy sought from the PFII was that it recommend that the NZ Government abandon the Foreshore and Seabed Bill; seek a halt discriminatory practices; and support the recommendations of external experts to establish an independent body capable of arbitrating disputes between indigenous peoples and states.

The PFII report to the important Economic and Social Committee (ECOSOC) of UN picked up on the situation in NZ including it among the issues in its report to ECOSOC. Of concern to many indigenous people at the PFII forum was New Zealand's reputation as a champion on the human rights globally following much lower standards at home.

\section{UN COMmitTEe ON ELIMINATION OF RACIAL DISCRIMINATION (CERD)}

Ngai Tahu and Treaty Tribes UN strategy included, along with a number of Maori groups and NGO's of presented interventions to the Committee on Elimination of Racial Discrimination (CERD). Whose role is to review states compliance with the convention on the elimination of racial discrimination, to conduct compliance and reviews, receive complaints from indigenous people, and invoke the important mechanism of 'early warning and early action procedures'.

In March of this year CERD released its report on the NZ Foreshore and Seabed issue, notable among the commentary was: 
(a) Its hope that all actors in NZ will refrain from exploiting racial tensions for their own political gain.

(b) Its concerned at the haste with which the legislation was enacted despite the State Party explanation.

(c) Insufficient consideration was given to alternative responses to the Ngati Apa decision which might have accommodated Maori rights within a framework more acceptable to both Maori and all other New Zealanders.

(d) Regretted that the consultation processes did not appreciably narrow the differences between the various parties.

(e) Noted the scale of opposition to the legislation among the group most directly affected by its provisions, ie; Maori, and the very strong perception by Maori that the legislation discriminates against them.

(f) CERD stated the legislation appears on balance to contain discriminatory aspects against Maori, in particular extinguishment of the possibility of establishing Maori customary title over the foreshore and seabed and lack of redress options. In contravention of the states obligations under articles five and six of the convention.

(g) CERD noted with appreciation the States tradition of negotiating with Maori on matters of importance to them and urges the States party, in a spirit of goodwill and in accordance with the ideals of the Treaty of Waitangi, to resume a dialogue with the Maori community with regard to the legislation, in order to seek ways of lessening its discriminatory effects, including where necessary through legislative amendment.

(h) CERD also requests the State party to monitor closely the implementation of the Foreshore and Seabed Act, its impact on the Maori population and the developing race relations in NZ, and to take steps to minimize any negative effects, especially by way of a flexible application of the legislation and by broadening the scope of redress available to Maori. (i) CERD also that the NZ government was intending to submit its fifteenth periodic report to the UN by the end of 2005 , and requested that include full information on the state of implementation of the Foreshore Seabed Act in the report.

It is significant that CERD rebuked Australia in 1999 for amending the Native Title Act 1993, the act originated as a result of the groundbreaking Mabo case regarding Aboriginal land rights the north of Australia. The 'roll back' amendment created certainty for government and third parties at the expense of indigenous title, and was applied across the whole of Australia. The New Zealand situation strongly reflects the actions of the Australian action of extinguishing and limiting customary title and rights in favour of government and third parties.

The CERD report sent a strong message to the New Zealand Government. Its findings justify the strong objection hapu and iwi made to the Foreshore and Seabed Bill. It also signalled a low point in Maori/ government relationships and was the catalyst for the emergence of the Maori Party as a political voice for 
Maori aspiration of self determination.

\section{CONCLUSION}

Much has changed since the colonial days, and yet in many respects so little. The fact is starkly obvious that fudging of human rights can still occur in this enlightened era. The absence of Maori presence from the hallways of power and influence for so long during the birthing of this nation has ensured the systems by which this country functions are rooted on the values and beliefs of colonial times. Maori communities in their own lands have been behind the eight ball, and their customs and rights are subject to the whims of the majority.

New Zealand lacks a constitution which embodies human rights that recognize and uphold the customary rights of the indigenous peoples of this land and protects customary rights from political acts of expediency that leave Maori in a state of uncertainty.

The energy and effort that Maori have applied since 1840 to bring these matters to a satisfactory conclusion has been a considerable tax on their resources, an effort that has largely been patient and respectful of the due process of law and order. Such patience, however, often sparks tension between young Maori who could be termed radical, and the traditional leadership who have a more moderate approach.

Trade offs have been attempted by various governments to cap their exposure to Treaty claims, rejected wholly by Maori, despite this rejection legislation has been enacted to give force to such 'tools'. For example, the treaty settlement process was ring fenced in the mid 90's to a fiscal cap of one billion dollars value. The sum total of treaty settlements to date has not reached the one billion dollar mark, and government policy recognizes the need to be flexible if all settlements are to be accommodated. The fisheries settlement was set at a much lower level, but since ratcheted up in value through excellent management by the Maori Fisheries Commission and its subsidiaries. Politics of convenience and the media have been key in creating the perception that Maori privilege is rife, often quantified by the amount of tax-payer funds being channelled into Maori initiatives. There is a failure to recognize the fact that Maori have who have settled their claims have done so for a decimal percentage, for example, 0.50 cents in the dollar on the 'dollar value' of their quantified loss of land and resources. It is not recognised that Maori might be taxpayers, that the tax take from Maori might exceed that which is applied to Maori targeted initiatives.

The Foreshore and Seabed outcome is a very good example for anyone wishing to study the phenomena of the power of the state to override its own principles in the name of political expediency.

In my experience, whanau, hapu and iwi efforts to retain their customary relationship with their lands, resources and customs, to sustain cultural vitality and connection is an energy sapping task. 
Holding the line on customary rights is a much more difficult task than can be imagined, despite the efforts of whanau, hapu and iwi. It is a case of 'might is right' and 'rights' might be ok if it suits.

Customary rights are central to connectedness with lands, resources, practices and knowledge retention, it is a struggle that particularly afflicts indigenous peoples world wide. Despite UN declarations such as the Decade of Indigenous Peoples, it is no different here in NZ, the Foreshore and Seabed issue testifies to that. 